\title{
Moral and Professional Accountability for Clinical Ethics Consultants
}

William Simkulet

Cleveland State University, w.simkulet@csuohio.edu

Follow this and additional works at: https://engagedscholarship.csuohio.edu/clphil_facpub

Part of the Ethics and Political Philosophy Commons, and the Philosophy of Science Commons How does access to this work benefit you? Let us know!

\section{Publisher's Statement}

This is an Accepted Manuscript of an article published by Taylor \& Francis in the American Journal of Bioethics in 2014, available online: http://wwww.tandfonline.com/10.1080/ 15265161.2014.900142.

\section{Repository Citation}

Simkulet, William, "Moral and Professional Accountability for Clinical Ethics Consultants" (2014).

Philosophy \& Comparative Religion Department Faculty Publications. 43.

https://engagedscholarship.csuohio.edu/clphil_facpub/43

This Article is brought to you for free and open access by the Philosophy \& Comparative Religion Department at EngagedScholarship@CSU. It has been accepted for inclusion in Philosophy \& Comparative Religion Department Faculty Publications by an authorized administrator of EngagedScholarship@CSU. For more information, please contact library.es@csuohio.edu. 


\section{Moral and Legal Accountability for Clinical Ethics Consultants}

In "Exploring Accountability of Clinical Ethics Consultants Practice and Training Implications," Kathryn Weise and Barbara Daly propose a model for the accountability of clinical ethics consultants (CEC from now on). Here I argue this account is insufficient, and offer a model for determining the responsibility of CECs.

Weise and Daly offer a two-part definition of accountability, where a CEC is accountable for her actions if and only if she accepts responsibility for her actions and is willing to disclose her responsibility to colleagues. CECs, Weise and Daly suggest, are unsure about the scope of their accountability. Although consultants do not have the final say in medical decisions, their recommendations can play an important role in matters of life and death. Weise and Daly reject the idea that CECs are ultimately responsible for the choices made by the group, or the outcomes of the medical procedures they advise on.

To be accountable for something is to be, in some relevant sense, responsible for that thing. With their two-part definition of accountability, I think Weise and Daly have confused two different kinds of responsibility - moral responsibility, and professional responsibility. The first requirement for accountability, on their model, requires that a CEC accepts responsibility for her actions; this account is similar to the compatibilist account of moral responsibility discussed in Fischer and Ravizza, according to which an agent is morally responsible if and only if she takes responsibility for her actions, where one takes responsibility by coming to see herself as an appropriate object for praise or blame. (1998) The problem with this account of responsibility is that an agent can take responsibility for anything, including things that are wholly outside of their control. 
Most philosophers, however, argue that moral responsibility requires control. (See Strawson 2002; Simkulet 2012) One problem with this commonsense view is that it makes sense to say that agents are responsible for the consequences of their actions even though these consequences are, ultimately, outside of our control. (See Zimmerman 1987) However, in each case in which it makes sense to hold an agent morally responsible for the consequences of her actions, the consequences are foreseeable outcomes of their free choices. Thus, we are merely derivatively morally responsible for the consequences of our actions, and truly morally responsible for our free choices. What makes our free choices morally praiseworthy or blameworthy is the intent, and care, with which we make them. The right thing is to do what one has the best reasons to do and to do it for those reasons.

Whether, and to what degree, one is morally responsible is a matter of what choices they make, and why. It is sometimes hard for external parties to judge who is morally responsible, and to what degree. Thus, when judging CECs, we ought to focus exclusively on professional responsibility. If we understand the second part of Weise and Daly's definition of accountability as an attempt to define professional responsibility, it comes up lacking. While transparency between consultants is desirable, it is a far cry from responsibility. Weise and Daly recognize that a CEC's primary obligation is to their patient's welfare. Were a CEC to put any other goal ahead of their patient's welfare, they are in clear breach of their professional ethics.

It is my goal here to offer a theory on the scope and degree of professional responsibility. Because we can only be properly held responsible for our free choices, the scope is clear - a CEC is professionally responsible for any free choice they make as a CEC. The degree of one's professional responsibility, I suggest, is equally clear - CECs are very responsible. CECs regularly deal with matters of life and death for their patients, and just medical physician is held 
to a high moral standards, so too should CECs. The degree of one's professional responsibility is determined by the subject matter of one's profession.

I will use the following case to illustrate the scope and degree of a CEC's professional responsibility. A clinical ethics consultant ends up with the deciding vote as to who will receive a replacement liver between patients A and B. The candidates are roughly equivalent, each is divorced with a young child, each needs a liver because of genetic factors, each donates time and money to charity, and each is in a relatively high risk profession - A is a police officer, while B is a fire fighter. Because both patients are similar, it would be understandable - and perhaps acceptable - for the consultant to use an arbitrary decision making process to choose between them - such as flipping a coin. Suppose that on her way to find a coin to flip, the consultant discovered some feature about patient A that the consultant disapproves of - A's religious beliefs, political beliefs, sexual orientation, or hair color - and for this reason votes that patient B should receive the organ, not patient $\mathrm{A}$.

It strikes me that the consultant's choice in this case would violate their professional responsibility. The problem here isn't the decision that the consultant makes, or the consequences of the decision - after all, she might just as easily have chosen patient B by flipping a coin; rather the problem is that she makes a life or death decision for irrelevant reasons. It is tempting to say that the consultant places her own personal moral values - in this case her disapproval of some medically irrelevant facet of patient A's life - above her duty to impartiality as a consultant; but this isn't correct. What makes an action morally good or bad is the reason one has to make it, the moral failing here is that the consultant's disapproval is morally suspect. Each of us has different moral beliefs, but we also have different reasons for our moral beliefs. A clinical ethics consultant might be morally justified in discriminating against a patient because 
of race, sex, religion, sexual orientation, or physical features if they have persuasive reasons to do so. For example, one might have been raised to believe that as people commit violence, their hair color turns a darker shade. Such a CEC might be morally justified in discriminating against dark haired people because they erroneously believe them to be vicious. To make sure that CECs don't make decisions based on erroneous beliefs, the medical profession requires transparency with regards to the reasons their CECs make decisions. In the case above, the CEC fails in their professional obligation to transparency, and fails to offer a substantive reason why patient A is morally inferior to patient $\mathrm{B}$.

\section{References}

Fischer, J. M., and Ravizza, M. 1998. Morally Responsible People without a Freedom. in Responsibility and Control: A Theory of Moral Responsibility. New York: Cambridge

Simkulet, W. 2012. On Moral Enhancement. American Journal of Bioethics Neuroscience 3(4) 17-18

Strawson, G. 2002. The impossibility of moral responsibility. In Ethical theory, Classic and contemporary readings, ed. L. P. Pojman. 
Weise, K., and Daly, B. 2014. Exploring Accountability of Clinical Ethics Consultants Practice and Training Implications. American Journal of Bioethics XX-XX

Zimmerman, M. J. 1987. Luck and Moral Responsibility. Ethics 97(2): 274-386 